\title{
Mengamalkan Nilai-Nilai Pancasila Ke Dalam Pendidikan Ditengah Pandemi Covid-19
}

\author{
Isfi Aulia Septiani ${ }^{1 *}$, Dinie Anggraeni Dewi ${ }^{2}$ \\ ${ }^{1,2}$ Universitas Pendidikan Indonesia Kampus Cibiru, Indonesia \\ *e-mail: isfiaulia12@gmail.com
}

\begin{abstract}
Pancasila is the ideology of the Indonesian nation which is the guideline or basis for regulating the life of all Indonesian people, especially in the field of education. The writing of this article uses a qualitative method, which is a research using available theory and data. The sources cited in this theory are journals, articles and theses. This study aims to find out how to practice the values contained in Pancasila in education in the midst of a Covid-19 pandemic like this The writing of this article is to use a qualitative research method or a descriptive approach. In this study, the results show that in Pancasila, there are five principles, each of which provides benefits to the Indonesian people, especially their practice in the field of education during the Covid19 pandemic like this.Education must continue to run even in these circumstances. Education is a powerful weapon to change the world, achieve the aspirations of the nation and be able to educate all generations of the Indonesian nation.
\end{abstract}

\section{Keywords: Pancasila, Education, Covid-19 pandemic}

\begin{abstract}
Abstrak : Pancasila merupakan ideologi bangsa Indonesia yang menjadi pedoman atau dasar yang mengatur kehidupan seluruh masyarakat Indonesia terutama dalam bidang pendidikan. Penulisan artikel ini menggunakan metode kualitatif yang merupakan penelitian dengan menggunakan teori dan data yang tersedia. Sumber-sumber yang dikutip pada teori ini berupa jurnal, artikel serta skripsi. Penelitian ini bertujuan untuk mengetahui bagaimana cara mengamalkan nilai-nilai yang termuat dalam Pancasila ke dalam Pendidikan di tengah pandemi covid-19 seperti ini. penulisan artikel ini adalah dengan menggunakan metode penelitian kualitatif atau pendekatan secara deskriptif. Di dalam penelitian ini diperoleh hasil bahwa di dalam Pancasila termuat lima sila, yang masing-masing dari sila tersebut memberikan manfaat bagi bangsa Indonesia, terutama pengamalannya dalam bidang Pendidikan pada masa pandemi covid-19 seperti ini. Pendidikan harus terus berjalan meski dalam keadaan seperti ini, Pendidikan merupakan senjata ampuh untuk merubah dunia, meraih cita-cita bangsa serta mampu mencerdaskan seluruh generasi bangsa Indonesia.
\end{abstract}

Keywords : Pancasila, Pendidikan, Pandemi covid-19

Copyright (c) 2021 The Authors. This is an open access article under the CC BY-SA 4.0 license (https://creativecommons.org/licenses/by-sa/4.0/)

\section{PENDAHULUAN}

Pancasila bagi bangsa Indonesia merupakan dasar negara atau menjadi pedoman serta petunjuk bagi kehidupan masyarakat Indonesia itu sendiri. Pancasila sebagai ideologi bangsa bersifat dinamis yang berarti menyesuaikan dengan perkembangan jaman, namun bukan berarti nilai-nilai yang terkandung di dalam Pancasila bisa diubah. Sebagai dasar negara Pancasila tentu memuat visi, misi serta 
tujuan dari bangsa Indonesia, dalam sejarahnya Pancasila itu memiliki akar sejarah yang cukup panjang. (Atma Jaya, 2018) Penamaan Pancasila sendiri ada beberapa usulan dari tokoh pejuang bangsa kemudian diambil nama pancasila. Menghadapi zaman yang serba canggih ini atau yang dikenal dengan arus globalisasi yang semakin pesat dimana kebudayaan barat mulai mempengaruhi kebudayaan lokal, hal ini juga berpengaruh pada Pendidikan di Indonesia. Keurgensian Pancasila sebagai dasar serta pedoman negara begitu dibutuhkan. Bahkan dikalangan anak milenial, nilai-nilai Pancasila mulai luntur. Contohnya pada sila ke-3 persatuan Indonesia, jika melihat dari bunyi sila ini setiap warga negara Indonesia harus saling membantu, tolong menolong tetapi nyatanya banyak sekali dari mereka yang lebih mementingkan dirinya sendiri, mereka acuh tak acuh, rasa ingin menang sendiri, karena mereka cenderung ingin menjadi seorang pemenang. Padahal seorang pemenang yang sejati adalah mereka yang mau mengalah demi kepentingan bersama bukan kepentingan dirinya sendiri.

Pandemi covid-19 memberi banyak dampak bagi keutuhan dan ketentraman bangsa Indonesia. Bangsa yang awalnya dalam keadaan baik-baik saja mendadak dilanda kegentingan, banyak orang yang menjadi korban dari keganasan wabah ini. Banyak pihak yang terkena imbas dari pandemi covid-19 ini, mulai dari bidang politik, sosial, ekonomi bahkan pendidikan. Kita bisa merasakan dampak dari wabah ini dimana yang awalnya setiap hari kita harus pergi ke sekolah untuk belajar dan menuntut ilmu, orang tua pergi bekerja namun sekarang sekolah harus dilakukan di rumah sedangkan hal ini dirasa kurang efektif karena guru tidak bisa terjun langsung melihat perkembangan peserta didik, orang tua banyak yang terkena PHK oleh perusahaan tempat mereka bekerja. Disini lah kita perlu mengamalkan nilai-nilai yang terkandung di dalam Pancasila, bangsa kita tengah mengalami krisis besar-besaran banyak dari mereka yang kelaparan, kehilangan pekerjaan akibat dari pandemi ini. Disaat situasi pandemi seperti ini bersatu padu seperti yang terkandung pada sila ke-3 itu sangat dibutuhkan untuk saat ini. Kita perlu bersatu untuk melawan masa krisis akibat dari pandemi ini agar negara kita tetap kokoh, tahan banting. Rasa persaudaraan harus tercipta, perbedaan dari segi ras, agama, bahasa atau bahkan kebudayaan bukan penghalang untuk bersatu sesuai dengan "Bhinneka Tunggal Ika” berbeda-beda namun tetap satu jua. 
Pandemi covid-19 ini memberikan dampak pada dunia pendidikan, sekolah yang semula bersifat konvensional atau tatap muka kini beralih menjadi online (Kemendikbud, 2020), adanya pandemi covid-19 ini tidak memungkinkan terjadinya pembelajaran secara tatap muka, pemerintah memprioritaskan keselamatan dan kesehatan peserta didik, pendidik, serta seluruh masyarakat. Perubahan sistem pendidikan ini tentu akan menimbulkan masalah baru serta kendala yang akan dihadapi guru, anak, juga orang tua di dalam menerapkan pembelajaran secara online ini. Dengan sistem pembelajaran daring ini tuntunan guru tentu akan semakin besar, dimana guru dituntut untuk lebih kreatif serta inovatif di dalam memberikan pengajaran, supaya anak tidak merasa jenuh. (Dewi, 2020) adanya pandemi ini membuat peserta didik mau tidak mau harus berhadapan dengan teknologi untuk mendukung pembelajaran, lalu anak juga akan merasa semakin berat karena mereka harus selalu mengikuti pembelajaran secara daring melalui teknologi sedangkan tidak semua anak serta orang tua memiliki fasilitas untuk pembelajaran daring, selain itu juga jaringan disetiap daerah itu berbeda terutama di daerah pedesaan yang jaringannya sangat dirasa kurang baik, sedangkan mereka harus paham terhadap materi yang guru sampaikan belum lagi tugas yang harus mereka kerjakan sedangkan fasilitas yang mereka miliki tidak memadai.

Dilihat dari permasalahan tadi maka perlu adanya kerja sama antar masyarakat untuk saling membantu masyarakat lainnya yang mengalami kesulitan. Sebagaimana pernyataan Agustina (2020), "solidaritas warga pada saat masa pandemi seperti ini menguat dalam membantu tenaga medis, maupun masyarakat yang ikut terdampak". Nilai-nilai Pancasila mulai dibutuhkan di masa pandemi seperti ini saat dimana masyarakat dengan sukarela ingin membantu meringankan kesulitan yang tengah terjadi saat ini. Menurut Mirsan (2020) nilai-nilai yang terkandung di dalam Pancasila dapat membantu kita dalam menjalankan kehidupan ditengah pandemi covid-19. Dengan diterapkannya seluruh sila dari Pancasila tersebut menandakan bahwa masyarakat untuk bergotong-royong, bahu membahu dalam menghadapi pandemi covid-19 ini.

\section{METODE}


Metode yang digunakan dalam penulisan artikel ini adalah menggunakan metode penelitian kualitatif. Penelitian kualitatif merupakan hasil penelitian yang didapat dari pengumpulan data serta teori dari para peneliti yang berhubungan dengan apa yang akan dibahas penulis pada artikel ini. Menurut (Sugiyono, 2018) metode penelitian adalah salah satu cara ilmiah dalam mendapatkan suatu data untuk tujuan dan kegunaan tertentu, penelitian kualitatif sendiri merupakan metode yang digunakan untuk meneliti pada tempat yang alamiah dan penelitian tidak membuat perlakuan, karena penelitian dalam menggunakan data bersifat empiris dengan kata lain yaitu berdasarkan pandangan dari sumber data seperti, jurnal, artikel serta skripsi bukan pandangan peneliti. Penelitian ini bertujuan untuk mengetahui bagaimana cara mengamalkan nilai-nilai yang termuat dalam Pancasila ke dalam Pendidikan di tengah pandemi covid-19 seperti ini.

\section{HASIL DAN PEMBAHASAN}

Pengamalan Pancasila dalam kehidupan berbangsa serta bernegara pada hakikatnya merupakan suatu hal atau cara untuk mencapai tujuan serta cita-cita nasional bangsa Indonesia. Tim penulis (1987) dasar negara merupakan pondasi dari bangunan negara yang artinya material terpenting dalam terciptanya suatu citacita bangsa. Febrihanuddin (2010) menyebutkan bahwa Pancasila itu hadir sebagai ruh kepribadian bangsa yang tujuannya untuk mengingatkan kita bahwa sesungguhnya bangsa Indonesia harus tetap bekerja sama serta bersatu padu, masalah yang disebabkan pandemi covid-19 ini merupakan kewajiban bersama artinya kewajiban seluruh bangsa Indonesia bukan hanya tanggung jawab pemerintah, aparatur negara melainkan tugas kita semua sebagai bangsa Indonesia supaya bisa mengembalikan kondisi bangsa seperti semula sebelum adanya pandemi ini.

Mahfud (2019) Nilai-nilai Pancasila merupakan pedoman serta sumber utama bagi ketertiban hukum yang ada di negara kita, bukan hanya itu saja namun juga sebagai moral bagi masyarakat Indonesia itu sendiri, terutama dalam masa pandemi seperti ini. Dalam kondisi pandemi seperti ini nilai yang terkandung pada Pancasila memberi perbaikan untuk menumbuhkan nilai empati, tenggang rasa serta cinta pada sesama, menjadi perekat bagi persatuan bangsa. Setiawan (2020) menyatakan bahwa dengan adanya pandemi covid-19 ini mendorong seluruh 
masyarakat Indonesia untuk hidup lebih bertanggung jawab kepada Allah SWT sumber yang memberi kita kehidupan kepada kita sesama manusia maupun kepada kesatuan bangsa Indonesia, merupakan komponen yang menjadi komponen bangsa untuk membuat nilai-nilai Pancasila terus tumbuh, tidak luntur dan berguna untuk keutuhan seluruh masyarakat serta bangsa Indonesia itu sendiri.

Rachman (2020) menyatakan bahwa nilai-nilai Pancasila merupakan hal yang paling mendasar, dalam memahami setiap nilai yang terkandung di dalam Pancasila diharapkan mampu mencegah terjadinya segala bentuk pelanggaran terhadap peraturan yang sudah dibuat oleh pemerintah yang berhubungan dengan penanganan pandemi covid-19 agar wabah ini cepat berlalu dan kondisi bangsa kembali stabil atau seperti semula sebelum adanya wabah pandemi covid-19 ini. Karena sesungguhnya peraturan itu dibuat untuk mencegah terjadinya suatu pelanggaran yang dirasa bisa merugikan masyarakat maupun bangsa Indonesia, dengan kata lain peraturan itu buat untuk kebaikan bersama. Laboratorium (1981) Pancasila merupakan dasar negara republik Indonesia. Secara bahasa dasar negara terdiri dari dua kata yang memiliki pengertian tersendiri. Kata pertama yaitu dasar berarti landasan atau suatu hal yang bersifat utama hal pertama yang sangat penting, kedua yaitu negara yang berarti suatu organisasi kekuasaan yang mana di dalamnya terdapat rakyat sebagai orang yang mendiami negara tersebut, wilayah yang menjadi tempat rakyat untuk berdiam diri dan yang terakhir yaitu pemerintahan.

\section{- Peran guru, anak, orang tua, serta pemerintah dalam pendidikan pada masa pandemi}

Pandemi covid-19 ini sangat berimbas terhadap bidang pendidikan, mulai dari sistem pembelajaran yang berubah dengan waktu yang tergolong singkat tanpa persiapan yang cukup matang atau bisa dikatakan mendadak. Namun proses belajar mengajar harus tetap berlangsung di tengah pandemi ini, pemerintah mengupayakan berbagai macam media ataupun alat yang bisa digunakan untuk proses belajar mengajar ini tetap berjalan dengan baik walaupun pada kenyataannya tidak seefektif sesaat sebelum adanya pandemi ini.

Peran guru, di dalam memberikan pengajaran pada masa pandemi seperti ini, dimana sistem pembelajaran yang berubah dari bersifat konvensional kini beralih menjadi daring (online) yang membuat guru harus lebih kreatif dan inovatif dalam 
memberikan pengajaran supaya anak tidak merasa jenuh dan paham dengan materi yang diberikan, namun guru juga mengalami kesulitan yang tidak bisa ditinjau secara langsung apakah anak paham dengan materi yang diajarkan dan solusi dari hal ini yaitu perlu adanya komunikasi atau kerja sama antara guru dengan orang tua.

Peran anak, selain guru yang mendapat tuntutan lebih, anak juga mendapat tuntutan yang sama, dimana anak dituntut untuk selalu hadir dalam pembelajaran daring, kemudian tugas-tugas yang guru berikan melalui daring juga, sedangkan pemahaman anak akan berbeda dengan pembelajaran tatap muka, anak dapat bertanya secara langsung kepada guru jika memang terdapat materi yang kurang dipahami, yang menjadi masalah lainnya yaitu tidak semua anak serta orang tua memiliki alat atau fasilitas untuk pembelajaran berbasis daring ini dan jika tidak ada alat yang bisa digunakan untuk pembelajaran daring ini anak tentu tidak bisa mengikuti pembelajaran dan akan membuat anak jadi tertinggal pembelajaran.

Peran orang tua, disaat pembelajaran berbasis daring menjadi salah satu faktor yang sangat penting dan sangat diperlukan oleh anak, terutama untuk anak yang masih dini, karena mereka sangat memerlukan pendampingan serta bimbingan dari orang tua yang menggantikan peran guru sebagai pengajar. Selain itu, peran penting lainnya adalah memberikan fasilitas kepada anak seperti handphone, laptop/komputer, kuota internet, dan media yang diperlukan untuk proses pembelajaran anak selama di rumah. Tetapi hal ini juga menyebabkan masalah lain atau kesenjangan karena pada saat pandemi seperti ini juga berdampak kepada mata pencaharian orang tua, banyak sekali orang tua atau masyarakat yang terkena PHK akibat perusahaan yang mengalami masalah imbas dari pandemi ini.

Peran pemerintah juga tidak kalah penting, salah satu peran penting pemerintah dalam memberikan kualitas pendidikan kepada anak generasi penerus bangsa, karena sesungguhnya Pendidikan merupakan kunci dari sebuah keberhasilan. Ditangan generasi muda lah kesuksesan negara itu. Peran pemerintah bisa dengan memberikan fasilitas seperti handphone, laptop, serta kuota internet kepada anak serta orang tua yang kurang mampu. Namun dalam memberikan dana ataupun bantuan pemerintah harus lebih selektif, agar dana atau bantuan yang diberikan itu jatuh kepada orang yang memang sangat membutuhkan, tidak sedikit kasus yang 
terjadi dimana bantuan dari pemerintah salah sasaran atau tidak diberikan kepada orang yang tepat. Selain itu, pemerintah berkewajiban untuk memberikan pelatihan atau bimbingan kepada pendidik/guru karena tidak semua pendidik itu menguasai teknologi terutama pendidik yang sudah lanjut usia, pemerintah juga perlu menyediakan media untuk pendidik supaya lebih mudah untuk melaksanakan pembelajaran masa pandemi saat ini. Sehingga bisa menghasilkan suatu pendidikan yang berkualitas meski dalam masa pandemi seperti ini.

\section{- Mengamalkan sila-sila dalam Pancasila di masa pandemi Covid-19}

Manik Sukoco (2019) mengatakan bahwa pada sila Ketuhanan yang Maha Esa, bangsa Indonesia mengakui bahwa sesungguhnya adanya Tuhan yang Maha Esa yang menjadi sumber kehidupan setiap orang termasuk masyarakat Indonesia. Dapat dikatakan jika sila pertama ini sudah tertanam dengan baik di dalam hati setiap masyarakat Indonesia maka keempat sila yang lainnya juga akan terlaksana dengan baik. Pandemi ini sudah merubah banyak hal di dunia ini termasuk kebutuhan untuk beribadah sesuai dengan agama kita masing-masing. Selain itu juga di bidang Pendidikan yang awalnya kita belajar di sekolah kini kita harus belajar di rumah, hal tersebut membawa pengaruh yang cukup besar, karena masyarakat Indonesia belum terbiasa dengan kondisi seperti sekarang ini. Jika merujuk pada sila pertama yaitu Ketuhanan Yang Maha Esa, pandemi Covid-19 ini tidak terlepas dari kehendak tuhan, artinya musibah ini memang sudah tuhan rencanakan maka dari itu teruslah berdoa dan berusaha agar wabah pandemi Covid19 ini cepat berlalu. Dan untuk saudara-saudara kita yang sudah menjadi korban dari musibah ini sudah menjadi kehendak Tuhan, kita hanya perlu mendoakan.

Kemanusiaan yang adil dan beradab, kita ambil kata terpenting dari sila ke-dua ini yaitu manusia, adil, beradab. pandemi Covid-19 ini hidup di dalam diri manusia, sebenarnya virus corona ini hampir mirip dengan flu burung yang menyerang pada hewan, seperti ayam yang sudah terkana flu burung itu akan mati dan dibiarkan begitu saja. Lain halnya dengan virus Covid-19 yang menyerang pada manusia, orang yang sudah terinfeksi virus ini maka akan diberi pengobatan, mereka tidak dibiarkan mati begitu saja oleh pemerintah, pemerintah menyediakan tim medis bahkan vaksin supaya orang yang sudah terkena virus ini bisa sembuh hal ini membuktikan sila ke-dua yaitu manusia diperlakukan dengan adil dan beradab. 
Di dalam menghadapi wabah ini perlu mengamalkan nilai yang termuat dari kelima sila pada pancasila, dalam hal ini juga dibutuhkannya kerja sama antara masyarakat dengan pemerintah. Jika pemerintah menerapkan aturan harus menjaga jarak, keluar rumah harus memakai masker maka sebagai bentuk kerja sama kita harus menaati peraturan tersebut. Menurut Mughai (2007:15) Implementasi nilainilai Pancasila dalam hidup bermasyarakat, berbangsa, dan bernegara sebagai akibat yang nyata dari kesadaran terhadap kehendak, berawal dari dalam diri manusia, sehingga memunculkan rasa keimanan, rasa kemanusiaan, rasa nasionalisme, rasa demokrasi, dan rasa keadilan bagi seluruh masyarakat indonesia. Dengan kata lain dengan adanya pandemi ini menjadi faktor yang mendorong seluruh masyarakat Indonesia untuk hidup lebih bertanggung jawab kepada Allah SWT sebagai sumber kehidupan, kepada sesama manusia juga kepada negara kesatuan republik Indonesia agar nilai-nilai yang terkandung di dalam Pancasila bisa kita amalkan dimasa pandemi seperti ini, kerja sama juga penting untuk bangsa agar semakin kuat dan kokoh dalam menghadapi masalah yang timbul akibat dari adanya pandemi ini.

Kaelan (2013) mengatakan bahwa Pancasila sendiri menjadi dasar negara Indonesia yang menjadi sumber dari segala sumber hukum yang ada di Indonesia. Pancasila disini menduduki posisi tertinggi sebagai sumber hukum dasar bangsa Indonesia. Oleh karena itu, setiap hukum yang ada bersumber atau tercermin dari Pancasila itu sendiri. Tidak ada yang bisa menyaingi kedudukan dari Pancasila sebagai sumber hukum tertinggi bangsa Indonesia, semua hukum yang ada merujuk pada Pancasila. Hal ini dapat dikatakan bahwa semua hukum yang ada di negara ini sudah sesuai dengan nilai yang terkandung didalam Pancasila. Semua masyarakat Indonesia wajib untuk menaati hukum yang berlaku karena hal ini sudah menjadi kesepakatan bersama demi keberhasilan bangsa ini. Di dalam mengamalkan Pancasila kita sebagai masyarakat yang baik bisa dengan mematuhi semua peraturan yang ada, hal mendasar yang perlu kita lakukan adalah dengan menaati peraturan yang ada di sekolah hal yang cukup sederhana namun sulit untuk dilakukan padahal setiap peraturan yang ada adalah untuk kebaikan kita semua. Namun, tidak semua orang menyadari akan hal itu mereka banyak yang mengabaikan peraturan yang sudah dibuat sebagai contoh peraturan yang banyak 
dilanggar oleh masyarakat adalah tidak menggunakan helm saat berkendara, banyak masyarakat yang mengabaikan hal tersebut, padahal menggunakan helm saat berkendara akan memberi perlindungan ketika berkendara.

Pengamalan Pancasila pada masa pandemi ini mengharuskan kita sebagai sesama manusia harus saling membantu satu sama lainnya tanpa kita harus melihat mereka dari suku, agama, ras serta budaya karna sesungguhnya kita satu yaitu Indonesia. Perbedaan bukan penghalang untuk kita bisa membantu orang yang sedang mengalami kesusahan. Satu bangsa yaitu Indonesia berarti kita adalah saudara sebangsa dan setanah air, tanah air tercinta Indonesia. Kita merupakan satu tubuh jika satu anggota tubuh merasa sakit maka anggota tubuh lainnya pun akan merasa sakit. Misalnya seperti yang terjadi pada saat ini bangsa kita tengah dilanda wabah virus corona, semua masyarakat, dan pemerintah negara bekerja sama saling membantu masyarakat lain yang kesusahan akibat dari virus tersebut. Sebagai masyarakat Indonesia kita harus menjadi satu, tidak terpecah belah dengan alasan apapun supaya bangsa kita menjadi bangsa yang kuat karena semua rakyatnya bersatu. Persatuan Indonesia bisa terwujud tidak hanya mengandalkan diri sendiri melainkan kita harus bekerja sama untuk mewujudkan cita-cita bangsa Indonesia. Kita telah mengetahui bahwa bangsa Indonesia itu merupakan bangsa yang kaya, baik dari hasil alamnya, budayanya, bahasa daerah serta suku dan wilayahnya. Dengan kekayaan tersebut menjadikan bangsa Indonesia sebagai bangsa yang makmur, akan terlihat lebih sempurna jika masyarakatnya bersatu dalam segala urusan. setiap masyarakat Indonesia harus mendapat keadilan dari berbagai bidang, baik politik, pendidikan dan sebagainya tanpa adanya perbedaan. terdapat kata "adil" yaitu adil dalam menempatkan sesuatu sesuai dengan porsinya, bisa juga menyelaraskan ataupun menyesuaikan antara hak dan kewajiban masyarakat Indonesia itu sendiri. Kita sebagai masyarakat Indonesia harus berani memperjuangkan keadilan baik untuk diri kita sendiri maupun untuk orang lain.

Pandemi Covid-19 ini memberikan suatu pelajaran persatuan indonesia yang jauh berbeda dari sebelum adanya pandemi ini, jika sebelum pandemi kita bisa bersatu dengan cara berkumpul, berpelukan, bahkan bertegur sapa secara langsung kini disaat adanya pandemi ini kita tentu saja tidak lagi bisa melakukan hal tersebut, namun kita bisa melaksanakan hal tersebut dengan hal yang lain misalnya dengan 
memberikan bantuan berupa donasi kepada saudara kita yang sudah terkena dampak dari pandemi ini, kita bisa memberikan dukungan kepada tim medis, perawat, juga relawan lewat media sosial, tentu saja di zaman sekarang ini zaman dimana teknologi semakin canggih kita bisa berkomunikasi jarak jauh dengan mudah bisa lewat laptop, handphone, juga media lainnya. Selain digunakan untuk pendidikan teknologi juga bisa digunakan untuk menolong saudara-saudara kita yang menjadi korban dari adanya virus ini, kita bisa memanfaatkan segala cara untuk membantu orang lain juga untuk diri kita sendiri,gunakan teknologi untuk hal-hal yang positif yang bisa memberikan manfaat bukan hanya untuk diri kita sendiri tapi juga untuk orang banyak. Jika memang kita termasuk ke dalam orang yang beruntung dalam segi ekonomi sebaiknya kita gunakan untuk membantu mereka yang mengalami kesulitan, terutama untuk hal pendidikan kita bisa memberikan sedikit bantuan untuk anak bangsa yang memang mengalami kesulitan dalam fasilitas untuk belajar kita tentu tahu betapa pentingnya pendidikan.

Menurut Muhamadi dan Hasanah (2019) menyatakan bahwa nilai-nilai Pancasila mulai terus mengalami kelunturan khususnya dikalangan generasi muda. Hal ini disebabkan oleh arus globalisasi yang semakin merembak. Penanaman setiap nilai dari Pancasila khususnya pada generasi muda tentunya akan membuat mereka semakin pintar bukan hanya pintar secara akademik juga non-akademik, juga menumbuhkan sikap toleransi dan punya literasi keagamaan yang baik, namun dalam penanamannya supaya lebih mudah yaitu perlu mengedepankan budaya mendengar dari pada budaya menggurui, maksud dari budaya dengar disini yaitu dengar apa yang generasi muda inginkan tentang Pancasila (prof. arry, 2021). Generasi muda tentu atau yang lebih dikenal dengan sebutan generasi milenial, mereka aktif disosial media oleh karena itu pemerintah bisa memanfaatkan hal tersebut dengan mencari tokoh (influencer) dimedia sosial yang bisa digunakan sebagai media untuk mengenalkan nilai-nilai Pancasila, carilah tokoh yang banyak digemari oleh anak generasi milenial. serta tokoh tersebut juga harus memiliki pengetahuan yang cukup kuat tentang Pancasila.

\section{- Contoh penerapan kelima sila dalam kehidupan sehari-hari}

Ketuhanan yang maha esa, mengandung makna cahaya kerohanian bagi setiap umat manusia. Setiap masyarakat Indonesia harus memiliki agama, setiap orang 
berhak memilih agama sesuai dengan keinginannya tidak boleh ada paksaan dari pihak manapun. Mereka harus menjalankan ibadah sesuai dengan ajaran agama yang mereka anut. Adapun penerapannya yaitu dengan cara beribadah dan berdoa serta juga saling menghargai antar umat beragama yang memang dimana setiap agama itu memliki perbedaan dalam pelaksanaan ibadahnya.

Kemanusiaan yang adil dan beradab, makna lambang rantai emas pada sila ke2 itu menggambarkan hubungan antar masyarakat yang ada di Indonesia harus diperlakukan secara adil dan beradab sehingga bisa menciptakan hubungan antar masyarakat Indonesia menjadi semakin kuat dan kokoh. Adapun penerapannya yaitu dengan cara saling membantu dan tidak memilih-milih dalam pertemanan, dalam pergaulan. Namun kita juga perlu menyaring pergaulan mana yang baik dan tidak.

Persatuan Indonesia, masyarakat Indonesia kita harus menjadi satu, tidak terpecah belah dengan alasan apapun supaya bangsa kita menjadi bangsa yang kuat karena semua rakyatnya bersatu. Persatuan Indonesia bisa terwujud bukan hanya mengandalkan diri sendiri melainkan kita harus bekerja sama untuk mewujudkan cita-cita bangsa Indonesia, menyatukan semua perbedaan yang ada. Adapun penerapannya yaitu bisa dengan cara mencintai produk dalam negeri, di zaman sekarang ini tidak sedikit masyarakat Indonesia yang lebih memilih produk luar dibanding dengan produk sendiri padahal produk dalam negeri tidak kalah bagus dari produk luar.

Kerakyatan yang dipimpin oleh hikmat kebijaksanaan dalam permusyawaratan perwakilan, makna yang terkandung pada sila ini yaitu nilai musyawarah, Musyawarah dilakukan oleh sekumpulan orang yang sedang berdiskusi atau membahas sesuatu untuk mengambil suatu keputusan yang sangat penting. Dengan kata lain musyawarah di Indonesia bisa berlangsung secara dengan baik bangsa Indonesia akan bersatu dan menjadikan bangsa Indonesia sebagai bangsa yang kuat. Musyawarah di Indonesia berjalan dengan baik maka akan semakin besar kemungkinan bangsa Indonesia mencapai cita-citanya. Maka tidak heran mengapa harus banteng yang menjadi lambang pada sila ke-4 karena banteng itu sesuai dengan isi yang ada pada sila kerakyatan yang dipimpin oleh hikmat kebijaksanaan dalam permusyawaratan perwakilan sudah jelas terlihat betapa 
kuatnya hewan yang satu ini.dimana sila tersebut termasuk kedalam sila ke-4. Adapun penerapannya yaitu dengan melakukan musyawarah serta diskusi dalam memecahkan suatu masalah dalam bidang apapun entah itu politik, ekonomi, sosial dan Pendidikan.

Keadilan bagi seluruh rakyat Indonesia, bahwa seluruh masyarakat Indonesia harus diperlakukan dengan adil dari segi apapun. Untuk padi sendiri melambangkan sandang pangan atau ketersediaan makanan dan kapas melambang sandang papan yang berarti menggambarkan ketersediaan pakaian. Jadi setiap masyarakat Indonesia memiliki hak atas sandang pangan serta sandang papan secara adil dan merata tanpa adanya yang membeda-bedakan. Suatu negara bisa dikatakan sejahtera apabila sandang pangan dan papannya terpenuhi. Adapun penerapannya yaitu melaksanakan piket dan bekerja sama. Dalam bidang Pendidikan, seluruh masyarakat Indonesia harus mendapat Pendidikan yang adil dan layak.

Dapat dikatakan sila pertama ini sudah tertanam dengan baik didalam hati setiap masyarakat Indonesia maka keempat sila yang lainnya juga akan terlaksana dengan baik. Pandemi ini sudah merubah banyak hal di dunia ini termasuk kebutuhan untuk beribadah sesuai dengan agama kita masing-masing dapat dilihat pada penjelasan di atas tadi. Selain itu juga dibidang pendidikan yang tadinya kita belajar di sekolah kini kita harus belajar di rumah yang membawa pengaruh yang cukup besar baik itu terhadap pemahaman siswa juga kepada psikis mereka, karena masyarakat Indonesia belum terbiasa dengan kondisi seperti sekarang ini. Namun Pancasila dapat dijadikan sebagai obat untuk mengatasi permasalahn ini.

Pendidikan di masa pandemi tentu terkena dampak yang cukup signifikan lembaga pendidikan seperti sekolah, kampus, yang tadinya melakukan pembelajaran dan perkuliahan secara konvensional (tatap muka) kini mau tidak mau, suka tidak suka harus mulai beradaptasi dengan perubahan sistem pendidikan yang berubah menjadi daring.

Terdapat pula tantangan guru di masa pandemi, seperti yang kita ketahui bahwa guru adalah tiang utama pendidikan, guru harus beradaptasi dengan sistem pembelajaran yang berubah secara tiba-tiba dapat dikatakan juga tanpa persiapan karena pandemi ini tidak pernah terfikir akan terjadi dan berlangsung lama. Guru juga harus berfikir keras karena pasti dengan perubahan ini motivasi siswa dalam 
nelajar akan mulai menurun drastis, guru juga harus ekstra dalam melakukan komunikasi dengan setiap orang tua siswa. Meski dalam persoalan yang cukup rumit guru tetap dituntut untuk tetap professional dalam melaksanakan pembelajaran supaya proses belajar mengajar bisa tetap berjalan.

Badrul (2019) mengatakan adapun peran Pancasila terhadap pendidikan Indonesia yaitu dimana Pancasila sebagai dasar negara Indonesia harus mampu memberikan acuan-acuan yang bisa membuat masyarakat Indonesia menjadi manusia yang berkarakter sehingga mampu membuat Pancasila dijadikan sebagai landasan teori untuk bisa menciptakan anak bangsa sesuai dengan apa yang tercermin didalam nilai setiap sila. Pancasila juga merupakan sumber nilai yang mampu untuk mengarahkan didalam proses Pendidikan supaya bisa menghasilkan anak bangsa yang mampu mengenali potensi yang ada didalam dirinya sehingga mampu menjalankan kehidupan dengan rasa penuh tanggung jawab dalam semua bidang dan dimensi yang ada dalam kehidupan. Tujuan pendidikan nasional yaitu untuk mengembangkan potensi serta kemampuan dan juga mampu membentuk suatu karakter serta peradaban bangsa yang memiliki martabat juga memiliki nilai tinggi dalam rangka mencerdaskan kehidupan bangsa dan juga sebagai pionir perubahan dunia dan yang lebih penting adalah untuk menjadi manusia yang bertaqwa kepada Allah SWT (tuhan yang maha esa), memiliki akhlak yang mulia, sehat jasmani serta rohani, berilmu, kreatif serta inovatif.

\section{SIMPULAN}

Pancasila bagi bangsa Indonesia merupakan dasar negara atau yang menjadi pedoman serta petunjuk bagi kehidupan masyarakat Indonesia itu sendiri. Pancasila juga merupakan sumber nilai yang mampu untuk mengarahkan di dalam proses pendidikan supaya bisa menghasilkan anak bangsa yang mampu mengenali potensi yang ada didalam dirinya sehingga mampu menjalankan kehidupan dengan rasa penuh tanggung jawab dalam semua bidang dan dimensi yang ada dalam kehidupan. Pandemi covid-19 ini memberikan dampak pada dunia pendidikan, sekolah yang semula bersifat konvensional atau tatap muka kini beralih menjadi online. Perubahan sistem pendidikan ini tentu akan memunculkan masalah baru 
juga kendala yang akan dihadapi guru, anak, serta orang tua di dalam menerapkan pembelajaran secara online ini. Dengan sistem pembelajaran daring tuntutan guru tentu akan semakin besar, dimana guru dituntut untuk lebih kreatif serta inovatif dalam memberikan pembelajaran, supaya anak tidak merasa jenuh. Lalu anak juga akan merasa semakin berat karena mereka harus selalu mengikuti pembelajaran secara daring melaui teknologi sedangkan tidak semua anak serta orang tua memiliki fasilitas untuk pembelajaran daring, selain itu juga jaringan disetiap daerah itu berbeda terutama didaerah pedesaan yang jaringannya sangat dirasa kurang baik, sedangkan mereka harus paham terhadap materi yang guru sampaikan belum lagi tugas yang harus mereka kerjakan sedangkan fasilitas yang mereka miliki tidak memadai.

Dalam permasalahan tersebut kita sebagai masyarakat Indonesia harus saling membantu untuk menyelesaikan masalah tersebut. Pengamalan Pancasila pada masa pandemi mengharuskan kita sebagai sesama manusia harus saling membantu satu sama lainnya tanpa kita harus melihat mereka dari suku, agama, ras serta budaya karna sesungguhnya kita satu yaitu Indonesia bisa dengan memberikan bantuan berupa memberikan media pembelajaran seperti handphone, laptop, kuota internet, pemerintah berkewajiban untuk memberikan pelatihan atau bimbingan kepada pendidik/guru karena tidak semua pendidik mahir dalam menggunakan teknologi terutama pendidik yang sudah lanjut usia, pemerintah perlu menyediakan media untuk pendidik supaya lebih mudah untuk melaksanakan pembelajaran saat ini. Sehingga bisa menghasilkan suatu pendidikan yang berkualitas meski dalam masa pandemi.

\section{DAFTAR RUJUKAN}

Agustina. S. S. 2020. Mencaga solidaritas, mencegah konflik akibat covid-19. (https://kompas.id/baca/riset/2020/05/19/menjagasolidaritasmencegahkonf $\underline{\text { likakibat-pandemi-covid19/) }}$

Arista, Aulia, Firdaus. (2021). Perubahan model dan karakteristik pembelajaran Pendidikan agama islam di masa pandemi covid-19. Tersedia : https://journalstkippgrisitubondo.ac.id/index.php/PKWU/article/view/92 
Atmajaya. (2018). Asal usul Pancasila. Tersedia: https://m.atmajaya.ac.id/web/Konten.aspx?gid=highlight\&cid=Asal-Usul$\underline{\text { Pancasila }}$

Badrul, ilmimubarak. (2019). Pancasila terhadap dunia Pendidikan.

Dewi, W. A. F. (2020). Dampak Covid-19 terhadap Implementasi Pembelajaran Daring di Sekolah Dasar. Edukatif: Jurnal Ilmu Pendidikan, 2(1), 55-61

Fany, Rachman. 2020. Kekuatan Pancasila dimasa sulit pandemi covid-19. Jakarta https://kumparan.com/maniksukoc o/memahami-pancasila.

Kaelan, M.S, Negara Kebangsaan Pancasila, (Yogyakarta: Paradigma 2013), hlm.687 Mirsan, adi. 2020. Nilai-nilai Pancasila dimasa pandemi covid19, Jakarta Hari, laksono. 2020. Peran Pancasila dalam kehidupan, Malang.

Kemendikbud. 2020. Penyesuaian keputusan empat Menteri tentang panduan pembelajaran di masa pandemi covid-19. Tersedia di : https://www.kemdikbud.go.id/main/blog/2020/08/penyesuaian-keputusanbersama-empat-menteri-tentang-panduan-pembelajaran-di-masa-pandemicovid19

Kristina. Presiden Jokowi ikut KTT LB G20 dari istana Bogor. Kementerian sekertariat negara republik Indonesia. March, 2020. https://www.Setneg.go.id/baca/index/presiden_jokowi_ikuti_ktt_lb_g20_d ari_istana_bogor

Laboratorium Pancasila, 1981, Pancasila Dalam Kedudukan Dan Fungsinya Sebagai Dasar Negara dan pandangan hidup bangsa Indonesia, Surabaya, Penerbit: Usaha Nasional. http:/lasoneartt.woedpress.com/ma kalah/falsafah-pancasilasebagaidasarfalsafah-negaraindonesia.

Mahfud MD, 2012, Makna dan Implikasi Pancasila sebagai Cita Hukum Dalam Peraturan Perundangundangan di Indonesia, Jakarta, Penyelenggara: Institut Leimena \& Center for Indonesian Constitutional Jurisprudence \& Hanns Seidel Foundation.

Manik, sukoco. Memahami Pancasila. Kumparan, March 14. 2019.

Mirsan, Adi. 2020. Nilai-nilai Pancasila dimasa pandemi covid-19, Jakarta 
393 | Jurnal Pendidikan dan Kewirausahaan Vol. 9 No. 22021

Mughai. 2007. Implementasi nilai-nilai Pancasila dalam hidup bermasyarakat berbangsa dan bernegara. 15. 2020.

Muhamadi. S. I., \& Hasanah. A. 2019. Penguatan Pendidikan karakter peduli sesame melalui kegiatan ekstrakulikuler relawan. Jurnal Pendidikan Agama Islam. XVI(1), 95-113.

Prov. Arry. (2021). Strategi khusus mengamalkan Pancasila digenerasi milenial.

Sugiyono. (2018). Metode Penelitian Kuantitatif, Kualitatif, dan R\&D. Bandung: Alfabeta.

Tim Penulis Jurusan PMPKN, 1987, Pancasila Dasar Negara Dan Pandangan Hidup Bangsa Indonesia, Malang, Penerbit: IKIP Malang. 